\title{
Pelatihan Manajemen Pertunjukan Virtual Seni Anak Usia Dini Berbasis Budaya Lokal
}

\author{
Intan Prastihastari Wijaya ${ }^{1}$, Dema Yulianto ${ }^{2 *}$, Linda Dwiyanti ${ }^{3}$, \\ Itot Bian Raharjo ${ }^{4}$, Sita Aulia Rahma 5 \\ 12,3,4,5 Program Studi PG-PAUD, Fakultas Keguruan dan Ilmu Pendidikan, Universitas Nusantara \\ PGRI Kediri, Kota Kediri, Jawa Timur, Indonesia.
}

Corresponding Email: dema@unpkediri.ac.id 2*.

\section{Article History:}

Received: Dec 24th 2021

Revised: Jan 03th 2022

Accepted: Jan 10th 2022

Published: Jan 27th 2022

Keywords: Management; Performance; Art; Early Childhood.
Abstract: Early childhood art performance management training is given to kindergarten teachers to make it easier for teachers to manage the need to organize virtual art performances for early childhood, and while still paying attention to the psychological aspects of early childhood. The participants of this local culture-based early childhood virtual art performance management training were representatives of the 12 people of Pokja 02 Kediri City Kindergarten teachers, and the implementation took place at Santo Yoseph II Kindergarten, Kediri City. The methods used in this training are lectures, question and answer discussions and demonstrations, and mentoring. The main resource persons for this training were the chairperson and members of the team proposing the application of science and technology for the community, namely 4 people, assisted by 1 student. The results of this local culture-based early childhood virtual art performance management training are very useful for teachers. It is felt that most teachers still lack the knowledge and skills to design virtual art performances for early childhood, and the training organized is very helpful for teachers in designing ideas for virtual art performances for early childhood. 


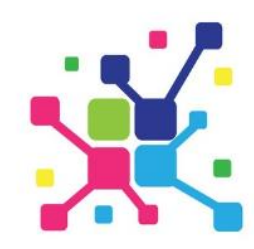

\section{Pendahuluan}

Sistem pendidikan pada masa pandemi Covid-19 ini membuat aspek kehidupan dan sistem pembelajaran menjadi berubah. Sesuai dengan surat edaran Mendikbud No. 4 Tahun 2020 [8], maka sistem pembelajaran dari semua jenjang lebih mengarah pada pembelajaran digital, dengan memanfaatkan teknologi informasi yang sudah berkembang dengan pesat, seperti whatsapp, google classroom, google meet, zoom, dan media informasi lainnya yang juga disebut dengan pembelajaran dalam jaringan (daring) secara virtual [1].

Proses pembelajaran daring sampai dengan saat ini dilakukan secara daring, sehingga perlu adanya nilai-nilai budaya tetap harus diberikan mulai dari anak usia dini. Salah satu cara untuk mengenalkan nilai budaya ke anak yaitu melalui kesenian. Pengenalan kesenian bagi anak usia dini mengandung unsur pendidikan seni yang perlu diketahui oleh anak, hal ini untuk melatih anak peduli dalam pemeliharaan budaya lokal dan mewujudkan masyarakat yang mencintai nilai-nilai luhur tanah air. Sementara itu, seperti yang dikatakan Tilaar (2000) bahwa pendidikan tidak hanya berpusat pada perkembangan intelektual saja, namun juga harus mempertunjukkan kegiatannya sebagai pusat penghayatan dan pengembangan budaya, baik budaya lokal, budaya nasional dan budaya global [2].

Selain itu, penguatan nilai budaya lokal juga penting untuk membentuk karakter anak sejak dini, supaya dapat membentengi dari distrubsi budaya. Oleh karena itu, berbagai inovasi pembelajaran untuk anak dilakukan oleh pengelola lembaga PAUD untuk kemajuan ilmu pengetahuan dan teknologi yang berbasis kearifan lokal dengan cara mengenalkan budaya-budaya yang ada di sekitarnya dan kebudayaan nasional [3]. Selain itu, pendidik juga harus memahami perkembangan anak didiknya, dan memperhatikan beberapa aspek antara lain, aspek psikologis, diktatis, dan pedagogis [4].

Penempatan seni dalam pendidikan dapat membantu pendidikan, dalam menumbuh kembangkan anak didik agar menjadi pribadi yang utuh, yaitu cerdas nalar serta rasa, sadar rasa kepribadian serta ras sosial, dan cinta budaya bangsa sendiri maupun bangsa lain [5]. Selain itu, pendidikan seni juga berperan mengembangkan kemampuan anak secara multilingual, multidimensial, dan multikultural, serta mengembangkan pengetahuan, keterampilan, dan kepribadian yang selaras dengan perkembangan mental, emosional, dan fisik anak [6]. Aspek psikologi juga berperan dalam pendidikan seni, karena aspek psikologi tersebut meliputi intelegensi, sikap, motivasi, minat, dan kreativitas.

Pengenalan budaya kepada anak usia dini dapat dilakukan dengan cara mengajak anak untuk ikut terlibat pada kegiatan-kegiatan seni pertunjukkan yang dilaksanakan oleh lembaga pendidikan atau di luar lembaga. Namun, kenyataannya dari hasil survei yang dilakukan oleh tim pengabdian ke beberapa sekolah (TK) yang ada di Kota Kediri, menyatakan bahwa seni pertunjukkan di sekolah merupakan kegiatan yang insidental, dan kegiatannya diselenggarakan setiap satu tahun sekali bertepatan dengan kegiatan 


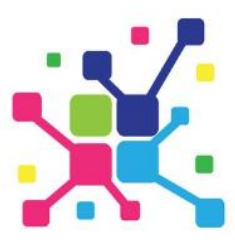

perpisahan. Dalam jangka waktu inilah, kegiatan seni pertunjukkan terbilang cukup lama, sehingga anak didik mengalami keterbatasan untuk mengekspresikan melalui gerak, apalagi saat ini sekolah terkendala dengan pembelajaran yang dilakukan secara daring dalam masa pandemi Covid-19 ini. Guru pun juga masih mengalami keterbatasan dalam menyiapkan konsep dan kebutuhan yang diperlukan saat menyelenggarakan pertunjukkan virtual seni anak usia dini. Padahal sistem pendidikan sekarang ini mengalami perubahan seiring dengan lajunya perkembangan ilmu pengetahuan dan teknologi [7], sehingga lembaga PAUD harus memiliki kualitas yang baik bagi kehidupan anak usia ini untuk berekspresi melalui kegiatan seni.

Oleh karena itu, pelatihan manajemen pertunjukkan seni anak usia dini perlu diberikan kepada guru-guru TK untuk memudahkan guru mengelola kebutuhan dalam menyelenggarakan pertunjukan virtual seni anak usia dini. Kegiatan ini bertujuan untuk memberikan pelatihan kepada guru atau peserta agar dapat menyelenggarakan pertunjukan seni anak usia dini pada acara perpisahan, wisuda anak, acara hari besar atau hari nasional, dan pada pertunjukan lainnya melalui pendekatan psikologi dan nilainilai budaya lokal, sehingga guru atau peserta mendapatkan pengalaman dalam membuat manajemen pertunjukan seni anak usia dini dengan baik.

\section{Metode}

a. Metode Pelaksanaan Kegiatan

Peserta pelatihan manajemen pertunjukan virtual seni anak usia dini berbasis budaya lokal adalah perwakilan guru-guru TK tingkat Pokja 02 Kota Kediri yang dihadiri 12 peserta dan pelaksanaan kegiatan ini bertempat di TK Santo Yoseph II Kota Kediri. Adapun narasumber utama pelatihan ini adalah ketua dan anggota tim pengusul penerapan Ipteks bagi Masyarakat yaitu empat orang. Mahasiswa yang berjumlah satu orang juga turut berpartisipasi untuk menyiapkan administrasi materi pelatihan, membantu dalam persiapan dan pendokumentasian kegiatan sebagai bentuk pemberian pengalaman dan pengetahuan mahasiswa PG-PAUD dalam kegiatan pengabdian masyarakat. Metode yang digunakan pada pelatihan ini yaitu ceramah, diskusi tanya jawab dan demontrasi serta pendampingan.

Alur metode pengembangan pelatihan ini adalah menganalisis masalah kemudian merumuskan solusi terkait pelaksaanaa manajemen pertunjukan virtual seni anak usia dini berbasis budaya lokal, kemudian melaksanakan pendampingan guru mitra di TK Santo Yoseph II Kota Kediri dalam merancang bentuk pertunjukan virtual. Selanjutnya alur metode kegiatan program pengabdian dapat dilihat pada bagian berikut ini.

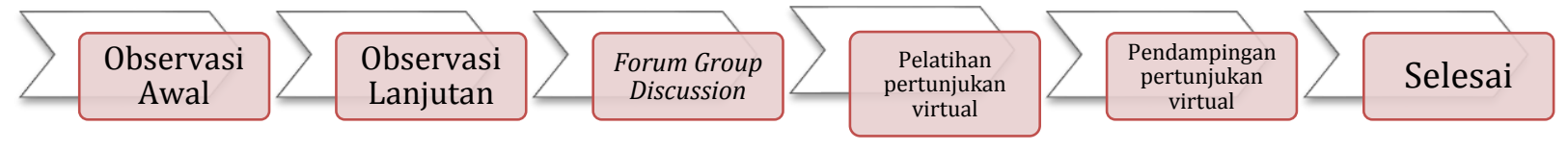

Gambar 1. Alur tahap pelaksanaan pengabdian. 


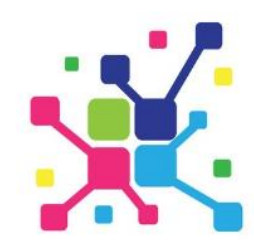

b. Waktu Efektif Pelaksanaan Kegiatan

Pelaksanaan kegiatan pengabdian kepada masyarakat tentang pelatihan manajemen pertunjukan virtual seni anak usia dini berbasis budaya lokal dilakukan pada tanggal 1619 November 2021 dengan waktu 32 jam.

\section{c. Tempat Kegiatan}

Pelaksanaan Kegiatan di TK Santo Yoseph II Kota Kediri dan diikuti Peserta berasal dari perwakilan guru-guru TK tingkat Pokja 02 Kota Kediri yang dihadiri 12 peserta.

\section{Hasil}

Pelaksanaan kegiatan pengabdian kepada masyarakat tentang pelatihan manajemen pertunjukan virtual seni anak usia dini berbasis budaya lokal dilakukan pada tanggal 16 - 19 November 2021 dengan waktu 32 jam. Adapun rincian kegiatan secara keseluruhan dapat dijelaskan pada tabel di bawah ini.

Tabel 1. Jadwal kegiatan pengabdian masyarakat

\begin{tabular}{|c|l|c|c|c|c|c|c|}
\hline \multirow{2}{*}{ No. } & \multicolumn{1}{|c|}{ Kegiatan } & \multicolumn{5}{c|}{ Bulan } \\
\cline { 3 - 7 } & & $\mathbf{1}$ & $\mathbf{2}$ & $\mathbf{3}$ & $\mathbf{4}$ & $\mathbf{5}$ & $\mathbf{6}$ \\
\hline 1. & Membentuk tim pengabdian kepada masyarakat. & & & & & & \\
\hline 2. & Melakukan koordinasi. & & & & & & \\
\hline 3. & Menyusun materi. & & & & & & \\
\hline 4. & Pelaksanaan. & & & & & \\
\hline 5. & Evaluasi kegiaatan pengabdian kepada masyarakat. & & & & & & \\
\hline
\end{tabular}

Sasaran pengabdian kepada masyarakat dari kegiatan ini yaitu para guru-guru anak usia dini yang ada di Kota Kediri, dimana para guru-guru TK menginginkan adanya inovasi pembelajaran sesuai kebutuhan saat ini, khususnya dalam pengembangan seni yang diwujudkan secara virtual berbasis budaya lokal namun tetap memperhatikan aspek psikologis anak usia dini. Tempat pelaksanaan kegiatan pengabdian kepada masyarakat di TK Santo Yoseph II Kota Kediri. Adapun semua peserta pelatihan terlihat antusias mendengarkan dan memperhatikan penjelasan materi yang disampaikan oleh semua narasumber. Selain itu, seluruh peserta juga penuh semangat untuk melaksanakan kegiatan praktek langsung sesuai tugas yang diberikan. Narasumber juga melakukan pendampingan ke peserta baik secara luring maupun secara daring melalui grup whatsapp. Sementara itu, hasil evaluasi penilaian dari peserta pada kegiatan ini, antara lain: (1) materi yang diberikan sangat bermanfaat dan sangat sesuai dengan kebutuhan lembaga TK (PAUD) saat ini; (2) penyampaian materi oleh narasumber sangat sesuai dengan topik materi; (3) semua narasumber sangat menguasai materi dan menyajikan materi dengan sangat menarik; (4) semua narasumber ikut terlibat mendampingi peserta dalam kegiatan praktik; (5) peserta berharap adanya pelatihan sejenis untuk menambah wawasan pengetahuan. 


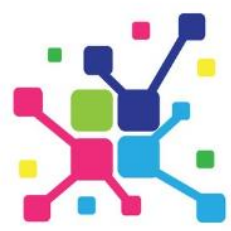

A J A D

Jurnal Pengabdian kepada Masyarakat

Vol. 2, No. 1, May, 2022, pp. 56-62 DOI : https://doi.org/10.35870/ajad.v2i1.38

\section{Diskusi}

Moderator acara sosialisasi ini adalah mahasiswa tingkat dua yang bernama Sita Aulia Rahma. Sesi pertama pemaparan materi dengan judul pengembangan aspek seni terhadap psikologis anak, disampaikan oleh Intan Prastihastari Wijaya, M.Pd., M.Psi. Adanya informasi tentang stimulasi pengembangan aspek seni dapat berdampak positif bagi anak, dimana anak lebih cerdas, kreatif, dan berkarakter. Sesi kedua pemaparan materi tentang strategi pembelajaran untuk anak usia dini disampaikan oleh Dr. Dema Yulianto., M.Psi. Sesi selanjutnya penyajian materi tentang manajemen seni pertunjukan visual, dengan metode kombinasi diskusi dan praktek disampaikan oleh Itot Bian Raharjo, S.Pd., M.M didampingi oleh Linda Dwiyanti, M.Pd. Materi pengembangan dan sekaligus mempraktikkan ini memang sangat dibutuhkan oleh guru taman kanak-kanak yang dapat dipraktikkan secara mandiri dengan aplikasi yang dapat dijangkau oleh guru.

Kegiatan forum group discussion dilaksanakan secara asinkronus untuk merancang pembuatan template pada pelaksanaan kegiatan seni atau non seni secara virtual. Apabila mengalami kendala dalam perancangan, para peserta dapat melakukan komunikasi dengan menanyakan hal yang dirasa sulit kepada narasumber. Pelaksanaan monitoring dilaksanakan untuk mengetahui apakah dalam merancang seni pertunjukan visual berbasis budaya lokal tersebut ada kendala atau tidak. Berikut dokumentasi manajemen pertunjukan virtual seni anak usia dini berbasis budaya lokal pada guru taman kanak-kanak.
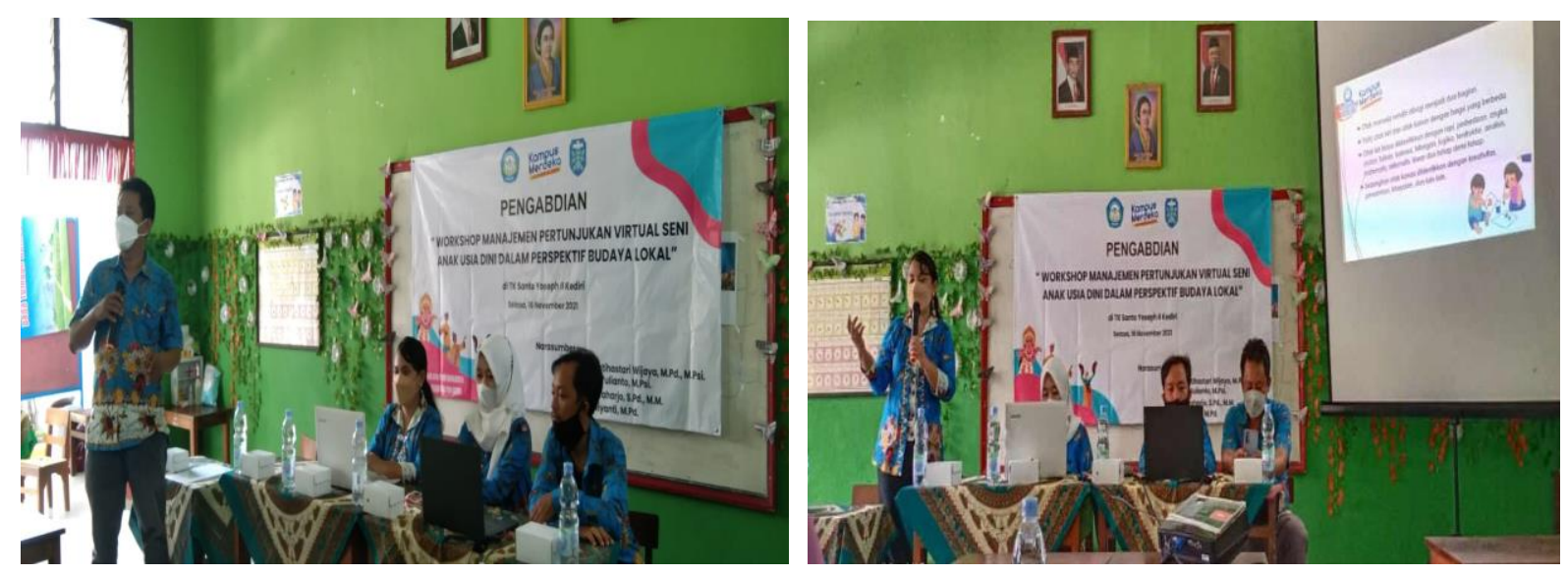

Gambar 2. Narasumber memberikan materi manajemen pertunjukan virtual seni anak usia dini berbasis budaya lokal. (Sumber: Data Tim PKM UNP Kediri, 2021) 


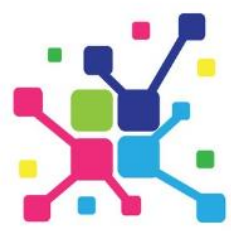

A J A D

Jurnal Pengabdian kepada Masyarakat

Vol. 2, No. 1, May, 2022, pp. 56-62

DOI : https://doi.org/10.35870/ajad.v2i1.38
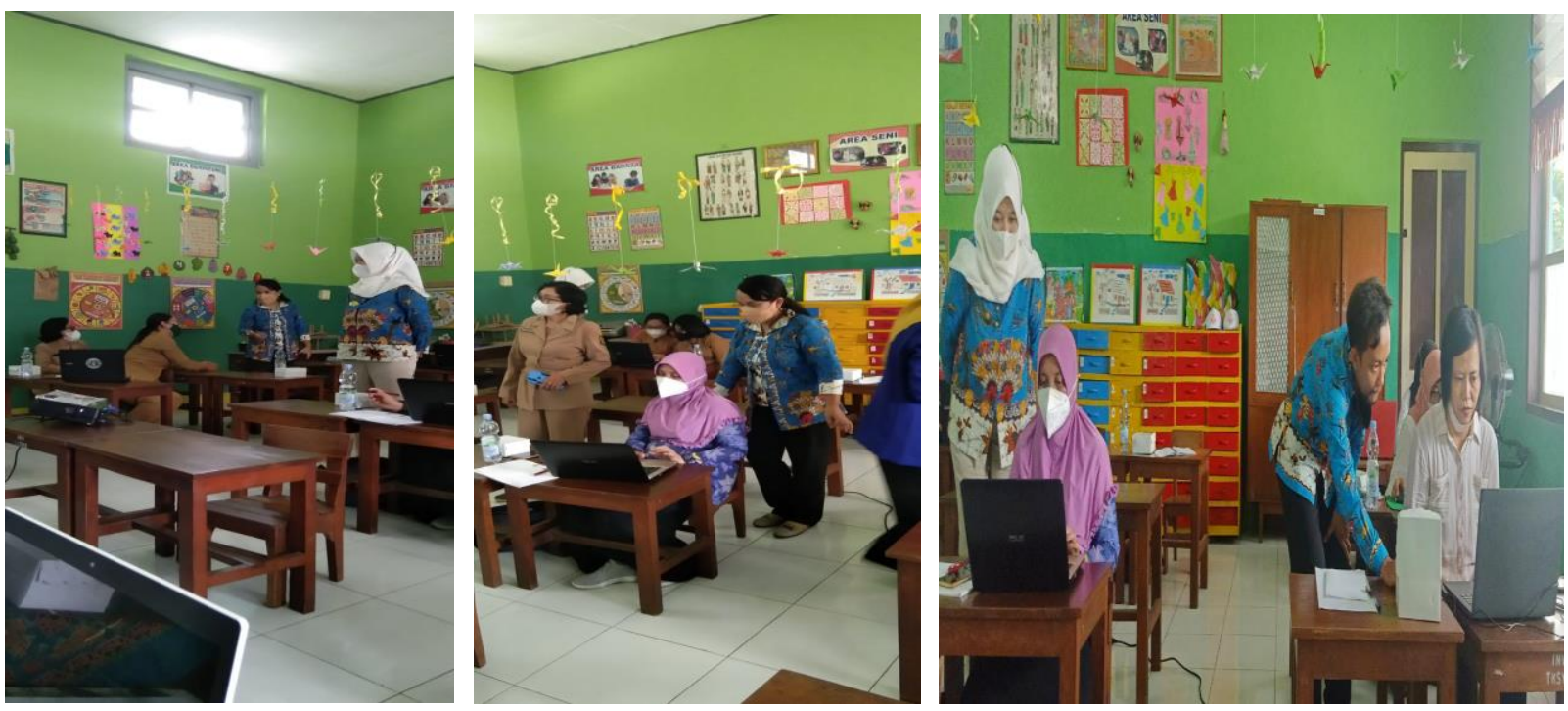

Gambar 3. Narasumber melakukan pendampingan manajemen pertunjukan virtual seni anak usia dini berbasis budaya lokal. (Sumber: Data Tim PKM UNP Kediri, 2021).

\section{Kesimpulan}

Secara umum kegiatan pengabdian masyarakat yang telah dilaksanakan dapat disimpulkan bahwa pelatihan manajemen pertunjukan virtual seni anak usia dini berbasis budaya lokal ini sangat bermanfaat bagi guru. Hal ini dirasakan bahwa sebagian besar guru masih kurang memiliki pengetahuan dan keterampilan merancang pertunjukan virtual seni anak usia dini, dan pelatihan yang diselenggarakan sangat membantu guru dalam merancang ide pertunjukan virtual seni anak usia dini. Pengetahuan dan keterampilan yang diperoleh peserta (guru) setelah mengikuti pelatihan dapat disosialisasikan kepada rekan sejawat guru TK, sehingga dapat memperbaiki dan meningkatkan pertunjukan virtual seni anak usia dini. Interaksi diantara rekan guru TK dalam praktik dapat terlihat bahwa para guru senang mendapatkan metode belajar mengajar yang lebih efisien.

\section{Ucapan Terima Kasih}

Ucapan terima kasih kami haturkan pada Universitas Nusantara PGRI Kediri melalui LPPM yang memberikan dana hibah stimulus pengabdian 2021. Dana tersebut sangat bermanfaat bagi kami selaku dosen dengan berkolaborasi bersama mahasiswa dalam meningkatkan kinerja untuk melaksanakan Tri Dharma Perguruan Tinggi dibidang Pengabdian kepada Masyarakat dan publikasi karya. 


\section{Daftar Referensi}

[1] Pakpahan, R., \& Fitriani, Y. 2020. Analisa Pemanfaatan Teknologi Informasi dalam Pembelajaran Jarak Jauh di Tengah Pandemi Virus Corona Covid-19. Journal of Information System, Applied, Management, Accounting and Research. 4(2), 30-36.

[2] Tilaar, H. A. R. 2000. Pendidikan, Kebudayaan, dan Masyarakat Madani Indonesia. Strategi Refomasi Pendidikan Nasional (cetakan ke-2). Bandung: Remaja Rosda Karya.

[3] Utami, W. Y. D., Jamaris, M., \& Meilanie, S. M. 2019. Evaluasi Program Pengelolaan Lembaga PAUD di Kabupaten Serang. Jurnal Obsesi: Jurnal Pendidikan Anak Usia Dini, 4(1), 67-76.

[4] Fatimah, D., Chan, F., \& Sofwan, M. 2021. Analisis Pelaksanaan Pembelajaran Daring Pada Masa Pandemi Covid-19 di Sekolah Dasar. Universitas Jambi.

[5] Rahman, U. 2009. Karakteristik Perkembangan Anak Usia Dini. Lentera Pendidikan: Jurnal Ilmu Tarbiyah dan Keguruan. 12(1), 46-57. D0I:10.24252/lp.2009v12n1a4.

[6] Saripudin, A. 2016. Peran Keluarga dalam Mengoptimalkan Perkembangan Motorik Anak Usia Dini. AWLADY: Jurnal Pendidikan Anak, 2(1), 1-18. DOI:10.24235/awlady.v2il.2585.

[7] Tilaar, H. A. R. 1998. Beberapa Agenda Reformasi Pendidikan Nasional "dalam Perspektif Abad 21". Magelang: Tera Indonesia.

[8] Surat Edaran Menteri Pendidikan dan Kebudayaan Nomor 4 Tahun 2020, tentang Pelaksanaan Kebijakan Pendidikan Dalamm Masa Darurat Penyebaran Corona Virus Disease (Covid-19). 